
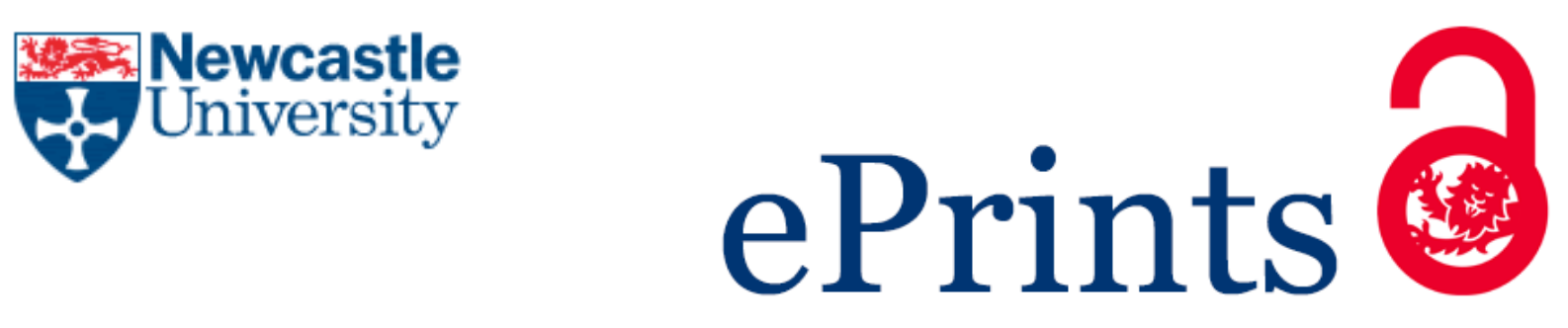

Eikemo T, Bambra C, Judge K, Ringdal K.

Welfare state regimes and differences in self-perceived health in Europe: a

multi-level analysis.

Social Science \& Medicine 2008, 66(11), 2281-2295.

\title{
Copyright:
}

(C) 2008. This manuscript version is made available under the CC-BY-NC-ND 4.0 license

DOI link to article:

http://dx.doi.org/10.1016/j.socscimed.2008.01.022

Date deposited:

$04 / 02 / 2017$

Embargo release date:

07 March 2008

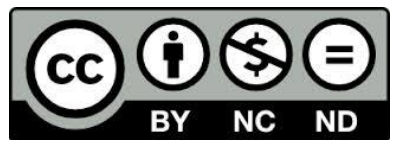

This work is licensed under a

Creative Commons Attribution-NonCommercial-NoDerivatives 4.0 International licence 


\section{Welfare state regimes and differences in self-perceived health in Europe: a multilevel analysis}

Word count

Main text: 5814

Main text including abstract, references, figure and tables: 8905 


\begin{abstract}
The aim of this study was to determine the degree to which welfare state regime characteristics explained the proportional variation of self-perceived health between European countries, when individual and regional variation was accounted for, by undertaking a multilevel analysis of the European Social Survey (2002 and 2004). A total of 65065 individuals, from 218 regions and 21 countries, aged 25 and above were included in the analysis. The health outcomes related to people's own mental and physical health in general. The study showed that almost $90 \%$ of the variation in health was attributable to the individual level, while approximately $10 \%$ was associated with national welfare state characteristics. The variation across regions within countries was not significant. Type of welfare state regime appeared to account for approximately half of the national-level variation of health inequalities between European countries. Scandinavian and Anglo-Saxon welfare regimes were observed to have better self-perceived general health in comparison to Southern and East European welfare regimes.
\end{abstract}

Keywords:

Health inequalities, welfare state, welfare state regimes, multilevel analysis, morbidity, Europe 


\section{Introduction}

The purpose of this paper is to examine and explain between country differences in self-perceived health in Europe by undertaking a multilevel analysis of the European Social Survey (2002 and 2004). It focuses on one main research question: to what extent does welfare state regime classification explain the proportional variation of self-perceived health between European countries, when individual and regional variation is accounted for? This not only implies a need to determine the degree to which self-perceived health actually varies between countries but also to examine whether (and if so, why) the characteristics of certain types of welfare state and welfare state regimes may have a health-protective effect.

\section{Welfare states and welfare state regimes}

It is now widely acknowledged that welfare states are important determinants of health in Europe as they mediate the extent, and impact, of socio-economic position on health (e.g. Bambra, 2006a; Eikemo, Huisman, Bambra, \& Kunst, in press; Navarro et al., 2003). Health status, especially inequalities in health within and between European countries, is largely determined by income inequalities, the distribution of wealth, and other aspects of socio-economic inequalities (Kawachi, Kennedy, Lochner, \& Prothrow-Stith, 1997; Mackenbach et al., 1997; Wilkinson, 1996). Welfare provision in its entirety (social transfers and welfare services) is designed to address these issues of inequality and should therefore have a bearing upon health outcomes (Bartley \& Blane, 1997; Conley \& Springer, 2001; Navarro et al., 2003) Welfare states provide a variety of social transfers (such as housing related benefits, unemployment, pensions, and sickness and disability benefits) as well as key services (most notably health care or social services), which together mediate the 
relationship between socio-economic position and health. The principles underpinning welfare states, the generosity of social transfers, and entitlements, vary extensively across European countries. For example, in some unemployment benefits are related to previous earnings (e.g. Norway, Germany) whereas in others they are provided at a standard flat-rate (e.g. UK) lowering the relative wage replacement rate (Eikemo \& Bambra, in press). Similarly, entitlement to welfare state benefits and services varies, with some countries providing universal coverage (e.g. Sweden or Norway) whilst others use means-testing (e.g. Ireland or UK).

Welfare state typologies place those welfare states that are the most similar (in terms of principles, provision, etc) together into clusters of countries with different welfare state regimes, emphasising within regime coherence and between regime differences. Influential within this field is the well known work of Esping-Andersen (1990). In The Three Worlds of Welfare State Capitalism (1990), he classifies welfare states into three regime types (Liberal, Conservative, Social Democratic) on the basis of three principles: decommodification (the extent to which an individual's welfare is reliant upon the market), social stratification (the role of welfare states in maintaining or breaking down social stratification), and the private-public mix (the relative roles of the state, the family and the market in welfare provision). A fourth principle, defamilisation ('the degree to which individual adults can uphold a socially acceptable standard of living, independently of family relationships, either through paid work or through social security provisions') (Lister, 1997) was added to the analysis in 1999 (Esping-Andersen, 1999). These principles reflect the relative roles of the state, the family and the market in the provision of welfare. Liberal (UK, Ireland) welfare states are characterised by their basic and minimal levels of 
provision: social transfers are modest and often attract strict entitlement criteria; recipients are usually means-tested and stigmatised; the dominance of the market is encouraged both passively, by guaranteeing only a minimum, and actively, by subsidising private welfare schemes. The conservative welfare state regime (Germany, France, Austria, Belgium, Italy and, to a lesser extent, the Netherlands) is distinguished by its 'status differentiating' welfare programs in which benefits are often earnings related, administered through the employer; and geared towards maintaining existing social patterns. The role of the family is also emphasised and the redistributive impact is minimal. However, the role of the market is marginalised. The Social Democratic regime type (Scandinavian countries), is characterised by universalism, comparatively generous social transfers, a commitment to full employment and income protection; and a strongly interventionist state. The state is used to promote social equality through a redistributive social security system.

There has been extensive scholarly debate about the theoretical and empirical value of the Three Worlds typology (for a detailed summary see Arts \& Gelissen, 2002 or Bambra, 2006b) and as a result of this, modified or alternative typologies have been proposed by others (Bambra C., 2004, 2005a, 2005b; Bonoli, 1997; Castles \& Mitchell, 1993; Korpi \& Palme, 1998; Navarro et al., 2006), most of which place emphasis on those characteristics of welfare states not extensively examined by Esping-Andersen or which cover more countries. Ferrera's (1996) four-fold typology, which focuses on different dimensions of how social benefits are granted and organised, has been highlighted as one of the most empirically accurate welfare state regime typologies (Bambra, 2007a). Ferrera makes a distinction between the Scandinavian (Social Democratic), Anglo-Saxon (Liberal), Bismarckian 
(Conservative) and Southern countries (Figure 1). Although there are clear similarities between Ferrera's and Esping-Andersen's typologies, Ferrera's classification is intended to account for differences in the way welfare is delivered whilst EspingAndersen's still tends to emphasise the quantity of welfare provided (Bambra, 2007a; Bonoli, 1997). In this way, the additional Southern regime is characterised by a fragmented system of welfare provision which consists of diverse income maintenance schemes that range from the meagre to the generous and a health care system that provides only limited and partial coverage. There is also a strong reliance on the family and charitable sector (Ferrera, 1996). One new challenge to conventional welfare regime typologies concerns the Eastern European countries. These countries have experienced extensive economic upheaval and have undertaken comprehensive social reforms throughout the 1990s (Kovacs, 2002). In comparison with the other member states of the European Union, they have limited health service provision and overall population health is relatively poor. In our analysis, we will use Ferrera's typology (1996) expanded by adding a category for Eastern Europe (Czech Republic, Hungary, Poland, and Slovenia).

\section{Health differences between individuals and regions}

Although the focus of this paper lies at country-level, it is important to consider health variations at the individual level additionally, because health is mainly attributed to individual characteristics. At this level, social inequalities in health have mainly been approached by means of occupational class (Kunst \& Mackenbach, 1994; Kunst et al., 2005), educational attainment (Cavelaars et al., 1998b; Silventoinen \& Lahelma, 2002) and income (Adler et al., 1994; Cavelaars et al., 1998a; Fritzell, Nermo, \& Lundberg, 2004; Marmot, 2002; Subramanian \& Kawach, 2006a; Subramanian \& 
Kawachi, 2004; Wagstaff \& van Doorslaer, 2000), all regarded as indicators of socioeconomic status (SES). We have also seen that social network (social contacts with one or several persons) and social support (quality of social interactions) appear to make individuals feel healthier, live longer, feel better and cope with difficulties due to chronic diseases and acute difficulties (Berkman, 1985; House, Landis, \& Umberson, 1988; Pinquart \& Sorensen, 2000; Wilkinson, 1999a, 1999b).

The data used in this study also allows us to investigate the proportional variation of self-perceived health among regions as compared to individual and country-level variation. Even though the extent to which self-perceived health varies among regions within European countries has not been previously investigated, we might expect that self-perceived health in Europe is also related to regional factors. Previous studies of mortality have shown that there is a regional north-south gradient in ischaemic heart disease mortality in both Britain and France, which could be partly explained by people's socioeconomic position (Lang et al., 1999; Morris et al., 2001). Another study concluded that ischaemic heart disease mortality is about $50 \%$ higher in East compared to West Germany (Muller-Nordhorn, Rossnagel, Mey, \& Willich, 2004).

\section{Health differences between countries and welfare state regimes}

Some European countries are healthier than others (Mackenbach, 2006) and the main aim of this study is to examine and explain disparities of self-perceived health in Europe by means of welfare state regimes, when individual and regional variation are accounted for. Welfare state regime typologies have previously been used to analyse cross-national differences in population health (Chung \& Muntaner, 2007; Coburn, 2004; Navarro et al., 2003; Navarro et al., 2006). These studies have invariably all 
concluded that population health is enhanced by the relatively generous and universal welfare provision of the Scandinavian countries (Chung \& Muntaner, 2007; Coburn, 2004; Navarro et al., 2003; Navarro et al., 2006). For example, studies have consistently shown that infant mortality rates (IMR) vary significantly by welfare regime type (Bambra, 2006a; Chung \& Muntaner, 2007; Coburn, 2004; Navarro et al., 2006), with rates lowest in the Scandinavian countries and highest in the Southern regimes. These systematic differences in health outcomes may be explained by the relative roles of the state, the family and the market in welfare provision (EspingAndersen, 1990) with the more highly decommodifying welfare states (Scandinavian) - through income redistribution (Dahl, Elstad, Hofoss, \& Martin-Mollard, 2006; Subramanian \& Kawachi, 2006b; Torsheim, Currie, Boyce, \& Samdal, 2006b; Torsheim et al., 2006a) and low unemployment (Ferrie, Shipley, Stansfeld, \& Marmot, 2002; Keefe et al., 2002; Lahelma, 1992; Martikainen \& Valkonen, 1996) - providing better protection against the health effects of a low market (socio-economic) position. Furthermore, the welfare state is important to population health in terms of how the state interacts with the family structure (Hatland, 2001), and thereby reduces the welfare burden on families and/or women (the state de-familises the family/women) (Bambra, 2004, 2007b; Esping-Andersen, 1999; Korpi, 2000).

Previous studies of health differences between welfare state regimes (e.g. Bambra, 2006a; Chung \& Muntaner, 2007; Coburn, 2004) have used mortality (especially IMR) or life expectancy data as their health outcomes (Navarro et al., 2006); they have tended to rely on Esping-Andersen's three-fold classification of welfare states (often excluding Southern and Eastern Europe), and they have seldom utilised a multilevel design (except for the studies of Olsen \& Dahl (2007) and Chung \& 
Muntaner (2007), in which two levels were applied). Therefore, this paper is the first to focus particularly on morbidity (self-perceived health) differences between welfare state regimes in Europe. This study is also distinguished from others in this field because we use a five-fold typology of welfare states, and we also use multilevel analysis with three levels.

\section{Data and methods}

This study is based on the cumulative data file (edition 2.0) for the first two rounds (fielded in 2002 and 2004) of the European Social Survey (ESS), which was released on January 29, 2007. The main objective of the ESS is to provide high quality data over time about changing social attitudes and values in Europe. Extensive descriptions of the ESS are at the ESS web site (www.europeansocialsurvey.org). The data and extensive documentation are freely available for downloading at the Norwegian Social Science Data Services (NSD) web site (www.nsd.uib.no). Available data from 65065 individuals (people aged $25+$ were included), within 218 regions (see appendix for detailed description), within 21 countries, were included in a multilevel analysis after deleting cases listwise by each variable in our analysis. The 21 countries were further defined into 5 types of welfare regimes.

\section{Health outcome variables}

We used two indicators of morbidity available in the ESS: self reported general health and limiting longstanding illness. Self reported general health was constructed from a variable asking; 'How is your (physical and mental) health in general?'. Eligible responses were 'very good', 'good', 'fair', 'bad', and 'very bad'. We dichotomized the variable into 'very good or good' health versus 'less than good' health ('fair', 
'bad', and 'very bad'). As for limiting longstanding illness, people were asked if they were hampered in daily activities in any way by any limiting longstanding illness or disability, infirmity or mental health problem. Eligible responses were 'yes a lot', 'yes to some extent' and 'no'. We dichotomized this variable into 'yes' (regardless of whether to some extent or a lot) and 'no'.

--- Table 1 about here ---

\section{Individual level explanatory variables}

The first explanatory variable is educational attainment, where people were asked to state their highest achieved level of education ranging from 'not completed primary education' to 'second stage of tertiary education'. We defined 'not completed primary education', 'primary or first stage of basic', and 'lower secondary or second stage of basic' as 'primary education', 'upper secondary' remains unchanged, while 'post secondary/non-tertiary', 'first stage of tertiary', and 'second stage of tertiary' are defined as 'post-secondary / tertiary education'. Occupational class was defined according to the European Socio-economic Classification (ESeC) (www.iser.essex.ac.uk/esec/), which is a further development of the widely applied EGP classification (Erikson \& Goldthorpe, 1992). The ESeC classification classifies people according to their positions within labour markets and production units, with special attention to their employment relations. The ESeC is designed to facilitate international overviews and cross-national comparisons across the EU (Rose \& Harrison, 2007). In order to improve population coverage, those who are not currently in paid employment are allocated to an ESeC class on the basis of their last main paid job. We applied a summary measure comparing classes 5 to 9 (lower occupational 
classes) with 1 to 4 (higher occupational classes). Those with unknown occupation were included in the analyses as 'no reported class' (see Table 1 for further description). Just over $7 \%$ of the respondents did not report any occupation and were included in the analysis with 'no reported occupation'. Income was measured by annual household income divided into four equal sized groups (quartiles). Individuals were classified into their relative economic income position within each country in order to control for different currencies and standards of living within the various countries. (To include more cases, an extra group consisting of people with no information on income, was added to the dummy-set). Social network was measured by frequency of social meetings with friends, relatives or colleagues. The response categories 'never', 'less than once a month', 'once a month' and 'several times a month' were recoded in to one group ('limited social network'), while the values describing 'once a week', 'several times a week', and 'every day' were set as the reference category. Social support was measured by quality of social meetings. The question asked was whether the person has anyone to discuss intimate or personal matters with. This variable was divided into two categories by the response categories 'yes' and 'no'.

\section{Country level explanatory variables}

We investigated whether type of welfare regime may contribute in explaining the health variation between countries by classifying the 21 countries into five different categories according to the Ferrera (1996) classification expanded by a category for Eastern Europe (Figure 1). More information about all explanatory variables at level 1 and 2 is given in Table 1. 
--- Table 1 about here ---

\section{Multilevel modelling}

Multilevel models are increasingly used within the social sciences because they allow the possibility of modelling outcomes as a function of explanatory variables at different levels. The basic principle is that the data are structured in hierarchically nested groups (Kreft \& Leeuw, 1998; Leyland \& Goldstein, 2004). The ESS allows for three hierarchic levels to be used. The level 1 units are individual people; the level 2 units are regions within countries, while the units at level 3 are European countries. By using general health and limiting longstanding illness as the dependent variables, we were able to investigate to what extent health varies at each level compared to the others and at the same time to seek to identify factors that may explain this variation.

The analyses were done in two steps. First, we analysed the variation in health without using any explanatory variables in order to decompose the variance of the intercept into variance components for each of the three levels (Table 2). Such models are called intercept-only models or just variance component models. The second step was to analyze a model with all the lower explanatory variables fixed, in order to see how health varies by means of individual characteristic such as sex, age and socioeconomic position (Table 3, Model 1). Thereafter, we added the country-level welfare regime variables (level 3) as shown in the second model of Table 3. The 3level logistic variance component model, which has no explanatory variables, may be written as follows:

$$
\begin{aligned}
& L_{i j k}=\beta_{0 j k} \\
& \beta_{0 j k}=\beta_{0}+V_{0 k}+U_{0 j}+e_{i j k}
\end{aligned}
$$


The expression $L_{i j k}$ represenents the linear logit function of the model. The intercept $\left(\beta_{0}\right)$ varies randomly across regions and countries, which is illustrated by the $j$ and $k$ subscript attached to it. The intercept for the $j$ th region is given by the average intercept $\beta_{0}$ plus a random departure $u_{0 j k}$. Following the same logic, the intercept for the $k$ th country will be the average intercept $\beta_{0}$ plus the random variation $v_{0 k} . e_{i j k}$ represents the individual-level residual. We can therefore say that the parameter $\beta_{0}$ constitutes the fixed part of the regression, while $u_{0 j k}$ and $v_{0 k}$ are random "residuals" on the regional and national level. The second step was to include explanatory variables:

$L_{i j k}=\beta_{0 j k}+\beta_{1} \mathrm{X}_{1 \mathrm{ijk}}+\beta_{2} \mathrm{X}_{2 \mathrm{ijk}}+\ldots+\beta_{\mathrm{n}+1} \mathrm{X}_{\mathrm{n}+\mathrm{ijk}}$

$\beta_{0 j k}=\beta_{0}+V_{0 k}+U_{0 j}+e_{i j k}$

The parameters were calculated using the software MLwiN. Browne (2003) and Goldstein (2003) advise the use of MCMC methods (with starting values based on the $2^{\text {nd }}$ PQL method) for binary response models. The big advantage of MCMC is that it allows exact interference, which is important for any level 3 parameters (such as variance) where the number of units is small. Alternatively we could have applied laplace methods, but these are also approximations to max likelihood and not always guaranteed to work well and quadrature can be very slow when there are a lot of parameters.

The parameter estimates in all models are given with $95 \%$ confidence intervals. For all multilevel models, we calculated the variance partition coefficient (VPC), which 
gives the proportion of the total variance that is attributable to each level. As the level 1 and $2+3$ variances are not on the same scale, we have used the latent variable approach (see Snijders \& Bosker (1999) for further details), by assuming the observed values (0 and 1) arise from an underlying continuous variable with logistic distribution. The variance of a standard logistic distribution is $\boldsymbol{\pi}^{\mathbf{2}} / \mathbf{3} \approx \mathbf{3 . 2 9}$ and the level 1 variance will be replaced by this value, so that both the level 1 and level $2+3$ variances are allocated on a continuous scale. For 3-level discrete response models, the VPC at country-level may calculated as $\left[V_{0 k} /\left(V_{0 k}+U_{0 j}+3.29\right)\right]$, the VPC at regional level as $\left[U_{0 k} /\left(V_{0 k}+U_{0 j}+3.29\right)\right]$, while individual-level VPC equals $[3.29 /($ $\left.\left.V_{0 k}+U_{0 j}+3.29\right)\right]$. We have presented these numbers as $\%$ of total variance $\left(\mathrm{VPC}^{*} 100\right)$.

\section{Results}

The interpretation of the results from Table 2 is very straightforward, as it simply shows how much of the total variance of self-perceived health that is attributed to each of the three levels. This is calculated as the ratio of the random country variance (i.e. the intercept) to the total variance. For example, the country-level variance of poor general health using the $2^{\text {nd }}$ order PQL method is 0.318 , which gives a proportional variance (in percent) of 8.68 . The calculation is $[0.318 /(3.29+0.054+$ $0.318))]^{*} 100$. Thus, roughly $8.68 \%$ of the variation of health is due to differences among the countries. At least four findings should be noted from Table 2 (3-level variance component models). First, the variation of peoples' general (poor) health is mainly caused by individual factors, as roughly $90 \%$ of the total variation is located here. Second, people's general health does not seem to vary much across regions within countries. Third, it appears that cases of limiting longstanding illness vary less 
than general poor health between European countries, as only $3.92 \%$ of the total variation was attributable at this level according to the $2^{\text {nd }}$ PQL-estimation. Because there is very little variation to explain with respect to limiting longstanding illness, we will only focus on poor general health in the following multilevel analyses. Finally, Table 2 compares the variance attributable at each level using different modelling techniques to test the sensitivity of this analysis to different methods. The results did not change substantially according to the various modelling technique. The forthcoming multilevel analysis with explanatory variables (Table 3) will thus be based on the Bayesian MCMC estimation with priors from $2^{\text {nd }}$ PQL method only.

--- Table 2 about here ---

The multilevel analyses shown in Table 3 (3-level random intercept models) include explanatory variables. Model 1 includes level-1 variables only and shows that having poor health is positively correlated with being older, being a woman, having only primary education, belonging to lower social classes, having low income, having a poor social network and not much social support. Largest health differences were observed between those with low (1st quartile) and high (4th quartile) income $(\mathrm{OR}=1.75)$ and between high and low educated people $(\mathrm{OR}=1.66)$. The variation in intercepts between countries indicates that $9.65 \%$ of the total variation of individual health outcomes is due to country-level characteristics, after we have adjusted for individual-level characteristics (Table 3).

The country-level variation is reduced from 0.355 (model 1) to 0.189 in model 2 after controlling for the welfare regime typologies, which means that the proportional 
variance is reduced from $9.65 \%$ to $5.43 \%$. This model shows that Scandinavian and Anglo-Saxon countries seem to have the best general health situation, while Southern welfare regimes and East European countries seem to have the worst general health compared to the Scandinavian countries. Bismarckian welfare regimes appear to hold an average position. The individual-level variables did not seem to change substantially from the first to the second model.

--- Table 3 about here ---

\section{Discussion}

Summarising the results, this study has shown that nearly $90 \%$ of the variation of selfperceived general health outcomes was due to characteristics at the individual level. Country-level characteristics accounted for around $10 \%$ of disparities in selfperceived health. Intra-country regional variation, however, was almost non-existent after controlling for individual and country level variation. The key finding of this study is that the Scandinavian and Anglo-Saxon welfare regimes seem to have arrangements that give them an advantage compared to Southern and East European welfare systems.

Before going deeper into this main finding, we have to consider some possible methodological limitations, which could influence this main result of the study. First, it is important to be aware of possible artefacts due to cultural differences in European countries. The fact that limiting longstanding illness may be regarded as a more robust measure than people's general health perception, combined with our finding that 
general health outcomes vary more at the national level compared to those of limiting longstanding illness, may indicate that possible biases due to different cultural health perceptions must be addressed. Results from a Finnish study, comparing cultural differences in self-rated health in Finland and Italy, suggest that self-rated health is a useful summary of physical health, but may be sensitive to cultural environment (Jylha, Guralnik, Ferrucci, Jokela, \& Heikkinen, 1998). We are therefore aware of the possibility that health expectations may vary according to culture and that direct cultural comparisons of self-rated health outcomes in general should be made with caution. The strength of this study, however, is that all questions are collected from the same survey, asking the same questions within the same period of time. Second, self-rated health is not as reliable as studies of mortality. However, a growing number of studies have shown that weaker measures of health are strongly correlated with harder health measures, such as death, both in the USA (Idler \& Benyamini, 1997) and in Europe (Heistaro, Jousilahti, Lahelma, Vartiainen, \& Puska, 2001). Third, the outcomes of poor general health might be sensitive to the cut off point on the health scale. Defining 'fair health' as 'good health' could change the between-country differences, as the category 'fair' may not be strictly comparable between countries. However, sensitivity analyses (not shown in tables) showed that the main pattern between the welfare regimes did not change when 'fair' was defined as 'good health'. Furthermore, defining 'fair' as 'poor health' has become more or less the standard procedure within social epidemiology and we have mainly done this for comparative reasons. Fourth, our analysis has not tested other attributes of countries such as GDP or income inequality. These might have associations with welfare regime and the relationships we have reported may therefore not be directly attributable to the welfare regimes as such, but possibly to other national factors that are not measured 
here. For example, differences between the Southern and Eastern European regimes on the one hand, and those of Northern Europe on the other hand, are perhaps due to the combined effects of the relative poverty of these countries (Olsen \& Dahl, 2007) (they have lower GDP per capita than the Bismarckian, Anglo-Saxon or Scandinavian countries), higher rates of smoking prevalence, the overhang of recent political upheavals and ex-dictatorship (Navarro et al., 2006), as well as the somewhat residual and fragmentary nature of their welfare state provision with its high reliance on the family and incomplete population coverage (Leibfreid, 1992). Finally, Bayesian estimation procedures vary according to different starting values. However, sensitivity analyses (not shown in tables) showed that our main results were not sensitive to different prior distributions. We also performed bootstrap estimations (using both MQL and PQL), which improves the accuracy of inferences about parameter values and corrects bias in parameter estimates (Goldstein \& Rasbash, 1996). These analyses also confirmed our main results.

\section{Individuals and regions}

Socioeconomic inequalities in health have been reported among individuals throughout Europe to a larger or lesser extent (Mackenbach \& Bakker, 2002). In our study, individual factors account for nearly $90 \%$ of differences in health status in our study. All of our indicators of socioeconomic status (SES) demonstrated a consistent pattern of health differences between groups of high and low SES. Not only were all associations significant; a perfect gradient was also observed with respect to the income quartiles and levels of education. These observations are supported by numerous studies, which have shown that people with privileged socio-economic status on the average have better general health and live longer than people with low 
socio-economic status (EUROTHINE - final report, 2007; Mackenbach, 2006; Siegrist \& Marmot, 2006). Self-perceived health did not seem to vary significantly among the 218 regions in this study when controlling for individual and country level variation. Although previous studies have shown that health indeed may vary by region when a limited number of regions are examined (Lang et al., 1999; Morris et al., 2001; Muller-Nordhorn et al., 2004) they do not seem to have an effect in a broader European perspective. However, these studies did control for both individual and country level variation.

\section{The links between welfare regimes and health status}

Welfare regime characteristics are important factors in explaining the variation of self-perceived health between different European populations, as they explain about half of the between-country variation in health. The main finding of this study is that there are differences in self-perceived health between different welfare state regimes and that the Scandinavian and Anglo-Saxon welfare regimes seem to have arrangements that give them an advantage compared to the Southern and East European welfare states.

That there are differences in self-perceived health between different welfare state regimes is perhaps not that surprising either empirically or theoretically. Previous empirical studies have also consistently identified such patterns (Bambra, 2006a; Chung \& Muntaner, 2007; Coburn, 2004; Navarro et al., 2006; Olsen \& Dahl, 2007). In theoretical terms, whilst all welfare states are designed to address issues of inequality, they do so in different ways and to different extents (Esping-Andersen, 1990). Empirically, this has been demonstrated in a number of studies. In a longitudinal cross-national study of income inequalities and welfare provision 
between countries, Coburn (2004) concluded that countries which were the least neoliberal in their economic and social policy orientation (i.e. the Scandinavian welfare states), had lower Infant Mortality Rates (IMR), and less mortality at younger ages. This study also suggested that welfare state regime might be the link between GDP/capita and mortality. Similarly, Bambra (2006a) found significant differences in IMR between Esping-Andersen's three worlds of welfare: weighted IMR for the Liberal (Anglo-Saxon), Conservative (Bismarckian) and Social Democratic (Scandinavian) regimes were 6.7, 4.5 and 4.0 respectively. This study also found a moderate correlation between decommodification levels (1998 data) and IMR ( $\mathrm{r}=-$ 0.585, $\mathrm{p}=0.018$ ). In another recent study of IMR, Navarro et al. (2006) examined differences between four different welfare state regimes (grouped in terms of political traditions), they found that those countries which have had long periods of government by redistributive political parties (most notably the Scandinavian countries) have experienced lower IMR and, to a lesser extent, increased life expectancy at birth. These findings were reinforced by Chung and Muntaneer's (2007) multilevel longitudinal analysis of welfare state regimes in which they found that around $20 \%$ of the difference in infant mortality rate among countries, and $10 \%$ for low birth weight, could be explained by the type of welfare state. Social Democratic (Scandinavian) countries had significantly lower IMR and low birth weight rates, compared to all other welfare state regimes (when the other three regimes in the analysis were combined). Our study reinforces and extends the results of these studies by showing that there are also differences between welfare state regimes in respect of morbidity (as measured by self-perceived health), when regional and country-level health variation is accounted for. 
Suggested explanations for the better performance of the Scandinavian welfare state regimes in terms of both mortality, and now morbidity, have varied. For example, Coburn (2004) and Bambra (2006a) have both suggested that the key characteristics of the Scandinavian welfare state package (universalism, generous replacement rates, extensive welfare services) result in narrower income inequalities and higher levels of decommodification, both of which are associated with better population health. For example, Wilkinson has highlighted that societies with lower income inequalities have better health than those with larger inequalities. Furthermore, higher decommodification is associated with lower infant mortality (Bambra, 2006a; Coburn, 2004). Coburn (2004), along with Navarro et al. (2003; 2006), have also highlighted the importance of the accumulative positive effect on income inequalities of governance by pro-redistribution political parties in the Scandinavian countries. Other commentators (for example Bambra et al., 2007b; or Stanistreet, Bambra, \& ScottSamuel, 2005) have also suggested that increased gender equality within the Scandinavian welfare states may be another incremental factor behind their better health outcomes. Furthermore, proponents of the social capital approach have highlighted the high levels of social cohesion and integration within Scandinavian societies (e.g. Putnam, 2000), something which has also been associated with better population health (e.g. Kawachi et al., 1997). Overall, following Chung and Muntaner (2007), the literature suggests that it is unlikely that there is one particular facet of the Scandinavian welfare model that leads to better health outcomes, rather it is the interaction and combination of a variety of policies (e.g. universal access to welfare services, higher replacement rates, higher levels of employment amongst both men and women), over a sustained period of time (Chung \& Muntaner, 2007; Navarro V. 
et al., 2006) which has led to a health enhancing reduction in material and social inequality.

Our study has also shown that self-perceived health is significantly worse in the Southern and Eastern European regimes. This result is also in keeping with the existing research literature as many studies have highlighted the comparatively poor performance of these countries (Bobak, Pikhart, Rose, Hertzman, \& Marmot, 2000; Carlson, 1998; Knesebeck, Verde, \& Dragano, 2006; Olsen \& Dahl, 2007) particularly in terms of mortality (see for example Leinsalu, Vagero, \& Kunst, 2003; Mackenbach, 2006; Shkolnikov et al., 2006; Valkonen, 2001). Although the existing research literature on health differences between welfare state regimes is unequivocal on the better performance of the Scandinavian welfare model, and the poorer performance of the Eastern and Southern European countries (Bambra, 2006a; Chung \& Muntaner, 2007; Coburn, 2004; Navarro et al., 2006; Olsen \& Dahl, 2007); it is less unanimous on the relatively poor performance of the Anglo-Saxon countries. Some studies (e.g. Bambra, 2006a; Coburn, 2004) have demonstrated the comparatively poor population health of Anglo-Saxon countries (particularly in terms of IMR). For example, Navarro and Shi (2001) and Coburn (2004) using a four-fold typology, and Bambra (2006a) using a three-fold typology of welfare state regimes, all found that IMR were significantly higher in the Anglo-Saxon countries than the Bismarckian or Scandinavian. Coburn (2004) also suggested that the Anglo-Saxon countries, due to their pursuit of more neo-liberal approaches (e.g. less public expenditure on welfare and a corresponding rise in reliance upon the market as a provider of welfare) did not experience the expected decreases in the period 19601995 in infant mortality due to their relatively high GDP/per capita (for example, in 
1960 the UK was ranked as 7th of 18 OECD countries in terms of IMR, by 1995 it had slipped to 13th). However, in contrast, the recent study by Chung and Muntaner (2007) of IMR and low birth weights by welfare state regime over a 39 year period found that when all four of the welfare state regimes used in the study were compared separately (rather than Scandinavian versus the other three regime types combined), there were no significant differences between the four regimes. Similarly, Coburn's (2004) study suggested that there were less pronounced differences in mortality in later life between the Anglo-Saxon countries and the other welfare state regimes and Navarro et al.'s (2006) study found less conclusive evidence of between regime differences for life expectancy.

Our study of variations in self-perceived health by welfare state regime therefore adds to this ongoing research debate. Given the uncertainty of the research literature in this area, it is only possible to speculate on possible explanations for the, somewhat counter-intuitive, performance of the Anglo-Saxon countries. One possibly quite substantial explanation which we would like to put forward is the role of health care services, an often overlooked social determinant of health (Chung \& Muntaner, 2007). Although the Anglo-Saxon countries in our European study - the UK and Ireland conform fairly well to the general characteristics of an Anglo-Saxon approach to social transfers e.g. use of means-testing, restrictive entitlement criteria, and low replacement rates (Esping-Andersen, 1990); they do not take a "typically" AngloSaxon market based approach to the provision of key welfare state services (Bambra, 2005a, 2005b). Most notably, health care is not provided by a market based system (as it is in the USA or Australia). For example, in the UK - like the Scandinavian countries - health care is provided via a National Health Service with similar coverage rates and low levels of private health care expenditure as in the 
Scandinavian countries (Bambra, 2005a, 2005b). It is possible that such highly decommodified health care services mediate the relationship between the otherwise Anglo-Saxon social transfer policies of the UK and Ireland, on self-perceived health. Clearly, more empirical examination of this and other possible explanations is required.

\section{Conclusion}

This study confirms what previous studies on the social determinants of health have shown; that socio-economic position is important in explaining disparities in health at the individual level. However, going further into the mechanisms of different welfare state regimes is an important path to follow in the process of identifying interventions to improve public health, as welfare regime appears to account for approximately half of the national-level variation of health inequalities among European countries. Scandinavian and Anglo-Saxon welfare regimes were observed to have better selfperceived general health than Bismarckian, Southern and East European welfare regimes. Welfare state characteristics such as levels of decommodification and the extent of welfare services might contribute to these differentials.

\section{References}

Adler, N. E., Boyce, T., Chesney, M. A., Cohen, S., Folkman, S., Kahn, R. L., et al. (1994). Socioeconomic-Status and Health - the Challenge of the Gradient. American Psychologist, 49(1), 15-24.

Arts W, \& Gelissen J. (2002). Three worlds of welfare or more? Journal of European Social Policy, 12, 137-158.

Bambra C. (2004). The worlds of welfare: Illusory and gender blind? Social Policy and Society, 3, 201-212.

Bambra C. (2005a). Worlds of welfare and the health care discrepancy. Social Policy and Society, 4, 31-41. 
Bambra C. (2005b). Cash versus services: 'worlds of welfare' and the decommodification of cash benefits and health care services Journal of Social Policy, 34, 195-213.

Bambra C. (2006a). Health status and the worlds of welfare. Social Policy and Society, 5, 53-62.

Bambra C. (2006b). Decommodification and the worlds of welfare revisited. Journal of European Social Policy, 16, 73-80.

Bambra C. (2007a). Sifting the wheat from the chaff: A two-dimensional discriminant analysis of welfare state regime theory. Social Policy and Administration, 41, $1-28$.

Bambra C. (2007b). Defamilisation and welfare state regimes: A cluster analysis. International Journal of Social Welfare, 16-326.

Bambra, C., Pope, D., Stanistreet, D., Swami, V., Kunst, A., \& Scott-Samuel, A. $(2007 \mathrm{c})$. Gender, health inequality and welfare state regimes: a cross-national study of twelve European countries. In Tackling Health Inequalities in Europe (EUROTHINE) Final Report. Rotterdam: ErasmusMC.

Bartley, M., \& Blane, D. (1997). Socioeconomic determinants of health: Health and the life course: Why safety nets matter. BMJ, 314, 1194.

Berkman, L. F. (1985). The relationship of social networks and social support to morbidity and mortality. In S. Cohen \& S. L. Syme (Eds.), Social support and health. Orlando: Academic Press.

Bobak, M., Pikhart, H., Rose, R., Hertzman, C., \& Marmot, M. (2000). Socioeconomic factors, material inequalities, and perceived control in selfrated health: cross-sectional data from seven post-communist countries. Social Science \& Medicine, 51(9), 1343-1350.

Bonoli J. (1997). Classifying welfare states: A two-dimension approach. Journal of Social Policy, 26, 351-372.

Browne, W. J. (2003). MCMC estimation in MLwiN. London: Institute of Education.

Carlson, P. (1998). Self-perceived health in East and West Europe: Another European health divide. Social Science \& Medicine, 46(10), 1355-1366.

Castles F., \& Mitchell D. (1993). Worlds of welfare and Families of Nations. In Castles F. (Ed.), Families of Nations: Patterns of Public Policy in Western Democracies. Dartmouth: Aldershot.

Cavelaars, A., Kunst, A. E., Geurts, J. J. M., Crialesi, R., Grotvedt, L., Helmert, U., et al. (1998b). Differences in self reported morbidity by educational level: A comparison of 11 Western European countries. Journal of Epidemiology and Community Health, 52(4), 219-227.

Cavelaars, A., Kunst, A. E., Geurts, J. J. M., Helmert, U., Lundberg, O., Mielck, A., et al. (1998a). Morbidity differences by occupational class among men in seven European countries: an application of the Erikson-Goldthorpe social class scheme. International Journal of Epidemiology, 27(2), 222-230.

Chung H., \& Muntaner C. (2007). Welfare state matters: A typological multilevel analysis of wealthy countries. . Health Policy, 80, 328-339.

Coburn D. (2004). Beyond the income inequality hypothesis: class, neo-liberalism, and health inequalities. Social Science \& Medicine, 58, 41-56.

Conley, D., \& Springer, K. (2001). Welfare state and infant mortality. American Journal of Sociology, 107, 768-807.

Dahl, E., Elstad, J. I., Hofoss, D., \& Martin-Mollard, M. (2006). For whom is income inequality most harmful? A multi-level analysis of income inequality and mortality in Norway. Social Science \& Medicine, 63(10), 2562-2574. 
Eikemo, T. A., \& Bambra, C. (in press). The welfare state: a glossary for public health. Journal of Epidemiology and Community Health.

Eikemo, T. A., Huisman, M., Bambra, C., \& Kunst, A. (in press). Health inequalities according to educational level in different welfare regimes: a comparison of 23 European countries. Sociology of Health \& Illness.

Erikson, R., \& Goldthorpe, J. H. (1992). The Constant Flux. Oxford: Clarendon Press. Esping-Andersen G. (1990). The three worlds of welfare capitalism. London: Polity.

Esping-Andersen G. (1999). Social foundations of post-industrial economies. Oxford: Oxford University Press.

European Social Survey. http://ess.nsd.uib.no.

European Socio-economic Classification home page. http://www.iser.essex.ac.uk/esec/.

EUROTHINE - final report. (2007). Tackling Health inequalities in Europe. Rotterdam: ErasmusMC.

Ferrera M. (1996). The southern model of welfare in social Europe. Journal of European Social Policy, 6, 17-37.

Ferrie, J. E., Shipley, M. J., Stansfeld, S. A., \& Marmot, M. G. (2002). Effects of chronic job insecurity and change in job security on self reported health, minor psychiatric morbidity, physiological measures, and health related behaviours in British civil servants: the Whitehall II study. Journal of Epidemiology and Community Health, 56(6), 450-454.

Fritzell, J., Nermo, M., \& Lundberg, O. (2004). The impact of income: assessing the relationship between income and health in Sweden. Scandinavian Journal of Public Health, 32(1), 6-16.

Goldstein, H., \& Rasbash, J. (1996). Improved approximations for multilevel models with binary responses. Journal of the Royal Statistical Society Series aStatistics in Society, 159, 505-513.

Hatland, A. (2001). Changing family patterns: A challenge to social security. In M. Kautto, J. Fritzell, B. Hvinden, J. Kvist \& H. Uusitalo (Eds.), Nordic welfare states in the European context (pp. 116-136). London and New York: Routledge.

Heistaro, S., Jousilahti, P., Lahelma, E., Vartiainen, E., \& Puska, P. (2001). Self rated health and mortality: a long term prospective study in eastern Finland. Journal of Epidemiology and Community Health, 55(4), 227-232.

House, J. S., Landis, K. R., \& Umberson, D. (1988). Social Relationships and Health. Science, 241(4865), 540-545.

Idler, E. L., \& Benyamini, Y. (1997). Self-rated health and mortality: A review of twenty-seven community studies. Journal of Health and Social Behavior, $38(1), 21-37$.

Jylha, M., Guralnik, J. M., Ferrucci, L., Jokela, J., \& Heikkinen, E. (1998). Is selfrated health comparable across cultures and genders? Journals of Gerontology Series B-Psychological Sciences and Social Sciences, 53(3), S144-S152.

Kawachi, I., Kennedy, B. P., Lochner, K., \& Prothrow-Stith, D. (1997). Social capital, income inequality, and mortality. American Journal of Public Health, 87(9), 1491-1498.

Keefe, V., Reid, P., Ormsby, C., Robson, B., Purdie, G., \& Baxter, J. (2002). Serious health events following involuntary job loss in New Zealand meat processing workers. International Journal of Epidemiology, 31(6), 1155-1161.

Knesebeck, O. V., Verde, P. E., \& Dragano, N. (2006). Education and health in 22 European countries. Social Science \& Medicine, 63(5), 1344-1351. 
Korpi W. (2000). Faces of inequality: gender, class and patterns of inequalities in different types of welfare states. Social Politics, 7, 127-191.

Korpi W., \& Palme J. (1998). The paradox of redistribution and the strategy of equality: welfare state institutions, inequality and poverty in the Western countries. American Sociological Review, 63, 662-687.

Kovacs, J. M. (2002). Approaching the EU and reaching the US? Rival narratives on transforming welfare regimes in East-Central Europe. West European Politics. , 25175 Sp. Iss. .

Kreft, I., \& Leeuw, J. (1998). Introducing multilevel modeling: Sage.

Kunst A., \& Mackenbach, J. P. (1994). Measuring socio-economic inequalities in health. Copenhagen: WHO Regional Office for Europe.

Kunst, A. E., Bos, V., Lahelma, E., Bartley, M., Lissau, I., Regidor, E., et al. (2005). Trends in socioeconomic inequalities in self-assessed health in 10 European countries. International Journal of Epidemiology, 34(2), 295-305.

Lahelma, E. (1992). Unemployment and Mental Well-Being - Elaboration of the Relationship. International Journal of Health Services, 22(2), 261-274.

Lang, T., Ducimetiere, P., Arveiler, D., Amouyel, P., Ferrieres, J., Ruidavets, J. B., et al. (1999). Trends and geographical disparities in coronary heart disease in France: are results concordant when different definitions of events are used? International Journal of Epidemiology, 28(6), 1050-1058.

Leibfreid, S. (1992). Towards a European welfare state. In Z. Ferge \& J. E. Kolberg (Eds.), Social policy in a changing Europe (pp. 245-279). Frankfurt: CampusVerlag.

Leinsalu, M., Vagero, D., \& Kunst, A. E. (2003). Estonia 1989-2000: enormous increase in mortality differences by education. International Journal of Epidemiology, 32(6), 1081-1087.

Leyland, A. H., \& Goldstein, H. (2004). Multilevel Modelling of Health Statistics: John Wiley \& Sons, ltd.

Lister R. (1997). Citizenship: Feminist Perspectives. London.

Mackenbach, J. P. (2006). Health Inequalities: Europe in Profile: An independent, expert report commissioned by, and published under the auspices of, UK Presidency of the EU.

Mackenbach, J. P., \& Bakker, M. (2002). Reducing inequalities in health: A European perspective: Routledge.

Mackenbach, J. P., Kunst, A. E., Cavelaars, A., Groenhof, F., Geurts, J. J. M., Andersen, O., et al. (1997). Socioeconomic inequalities in morbidity and mortality in western Europe. Lancet, 349(9066), 1655-1659.

Marmot, M. (2002). The influence of income on health: Views of an epidemiologist. Health Affairs, 21(2), 31-46.

Martikainen, P. T., \& Valkonen, T. (1996). Excess mortality of unemployed men and women during a period of rapidly increasing unemployment. Lancet, 348(9032), 909-912.

Morris, R. W., Whincup, P. H., Lampe, F. C., Walker, N., Wannamethee, S. G., \& Shaper, A. G. (2001). Geographic variation in incidence of coronary heart disease in Britain: the contribution of established risk factors. Heart, 86(3), 277-283.

Muller-Nordhorn, J., Rossnagel, K., Mey, W., \& Willich, S. N. (2004). Regional variation and time trends in mortality from ischaemic heart disease: East and West Germany 10 years after reunification. Journal of Epidemiology and Community Health, 58(6), 481-485. 
Navarro V., Borrell C., Benach J., Muntaner C., Quiroga A., Rodriquez-Sanz M., et al. (2003). The importance of the political and the social in explaining mortality differentials among the countries of the OECD, 1950-1998. International Journal of Health Services Research, 33, 419-494.

Navarro V., Muntaner C., Borrell C., Benach J., Quiroga A., Rodríguez-Sanz M., et al. (2006). Politics and health outcomes. Lancet, 368, 1033-1037.

Navarro V., \& Shi L. (2001). The political context of social inequalities and health. International Journal of Health Services Research, 31, 1-21.

Norwegian Social Science Data Services. http://www.nsd.uib.no.

Olsen, K. M., \& Dahl, S. A. (2007). Health differences between European countries. Social Science \& Medicine, 64(8), 1665-1678.

Pinquart, M., \& Sorensen, S. (2000). Influences of socioeconomic status, social network, and competence on subjective well-being in later life: A metaanalysis. Psychology and Aging, 15(2), 187-224.

Putnam, R. D. (2000). Bowling alone. The collapse and revival of American community. New York: Simon \& Schuster.

Rose, D., \& Harrison, E. (2007). The European socio-economic classification: A new social class schema for comparative European research (Vol. 9, pp. 459 - 490): Routledge.

Shkolnikov, V. M., Andreev, E. M., Jasilionis, D., Leinsalu, M., Antonova, O. I., \& McKee, M. (2006). The changing relation between education and life expectancy in central and eastern Europe in the 1990s. Journal of Epidemiology and Community Health, 60(10), 875-881.

Siegrist, J., \& Marmot, M. (2006). Social inequalities in health. New evidence and policy implications. Oxford: University Press.

Silventoinen, K., \& Lahelma, E. (2002). Health inequalities by education and age in four Nordic countries, 1986 and 1994. Journal of Epidemiology and Community Health, 56(4), 253-258.

Snijders, T., \& Bosker, R. (1999). Multilevel analysis. An introduction to basic and advanced multilevel modeling. London: Sage.

Stanistreet, D., Bambra, C., \& Scott-Samuel, A. (2005). Is patriarchy the source of men's higher mortality? Journal of Epidemiology and Community Health, 59(10), 873-876.

Subramanian, S. V., \& Kawach, I. (2006a). Being well and doing well: on the importance of income for health. International Journal of Social Welfare, 15, S13-S22.

Subramanian, S. V., \& Kawachi, I. (2004). Income inequality and health: What have we learned so far? Epidemiologic Reviews, 26, 78-91.

Subramanian, S. V., \& Kawachi, I. (2006b). Whose health is affected by income inequality? A multilevel interaction analysis of contemporaneous and lagged effects of state income inequality on individual self-rated health in the United States. Health \& Place, 12(2), 141-156.

Torsheim, T., Currie, C., Boyce, W., \& Samdal, O. (2006b). Country material distribution and adolescents' perceived health: multilevel study of adolescents in 27 countries. Journal of Epidemiology and Community Health, 60(2), 156161.

Torsheim, T., Ravens-Sieberer, U., Hetland, J., Valimaa, R., Danielson, M., \& Overpeck, M. (2006a). Cross-national variation of gender differences in adolescent subjective health in Europe and North America. Social Science \& Medicine, 62(4), 815-827. 
Valkonen, T. (2001). Trends in differential mortality in European countries. In J. Vallin, F. Meslé \& T. Valkonen (Eds.), Trends in mortality and differential mortality (Vol. 36, pp. 185-300): Council of Europe Publishing, Population Studies.

Wagstaff, A., \& van Doorslaer, E. (2000). Income inequality and health: What does the literature tell us? Annual Review of Public Health, 21, 543-567.

Wilkinson, R. G. (1996). Unhealthy societies. London: Routledge.

Wilkinson, R. G. (1999a). Income inequality, social cohesion, and health: Clarifying the theory - A reply to Muntaner and Lynch. International Journal of Health Services, 29(3), 525-543.

Wilkinson, R. G. (1999b). Health, hierarchy, and social anxiety. In Socioeconomic Status and Health in Industrial Nations (Vol. 896, pp. 48-63).

\begin{tabular}{ccccc}
\hline Scandinavian & Anglo-Saxon & Bismarckian & $\begin{array}{c}\text { Eastern } \\
\text { European }\end{array}$ & Southern \\
\hline & & Austria & & \\
Denmark & & Belgium & \\
Finland & United Kingdom & France & Czech Republic & Greece \\
Norway & Ireland & Germany & Hungary & Italy \\
Sweden & & Puxembourg & Poland & Portugal \\
& & Netherlands & Slovenia & Spain \\
& & Switzerland & & \\
\hline
\end{tabular}

Figure 1: Categorisation of European countries 
Table 1 Descriptive statistics for the variables to be analysed ${ }^{a}$

\begin{tabular}{|c|c|c|c|c|}
\hline Variables & Description & Min. & Max. & Percent $^{\mathrm{b}}$ \\
\hline \multicolumn{5}{|c|}{ Subjective poor health ( $n=65065)$} \\
\hline Poor health & $\begin{array}{l}\text { Poor general health ('very bad', 'bad' and 'fair health' as } \\
\text { compared to 'good' and 'very good' health) }\end{array}$ & 0 & 1 & $36.15 \%$ \\
\hline $\begin{array}{l}\text { Limiting longstanding } \\
\text { illness } \\
\text { Demographic }\end{array}$ & $\begin{array}{l}\text { Hampered by a limiting longstanding illness ('yes' and 'to } \\
\text { some extent' as compared to 'no') }\end{array}$ & 0 & 1 & $26.12 \%$ \\
\hline Age & Age in years & 25 & 109 & 50.75 \\
\hline $\begin{array}{l}\text { Women } \\
\text { Socio-economic status }\end{array}$ & \multicolumn{3}{|c|}{ Socio-economic status } & $49.88 \%$ \\
\hline Primary education & Primary education & 0 & 1 & $41.60 \%$ \\
\hline Upper sec. education & Upper secondary education & 0 & 1 & $32.74 \%$ \\
\hline Tertiary education & Tertiary education (reference category) & 0 & 1 & $25.66 \%$ \\
\hline $\begin{array}{l}\text { Lower occupational } \\
\text { classes }\end{array}$ & $\begin{array}{l}\text { (5) Self employed occupations (agriculture etc). (6) } \\
\text { Lower supervisory and lower technician occupations. (7) } \\
\text { Lower services, sales and clerical occupations. (8) Lower } \\
\text { technical occupations. (9) Routine occupations. }\end{array}$ & 0 & 1 & $46.80 \%$ \\
\hline $\begin{array}{l}\text { Higher occupational } \\
\text { classes }\end{array}$ & $\begin{array}{l}\text { (1) Large employers, higher grade professional, } \\
\text { administrative and managerial occupations. ( } 2 \text { ) Lower } \\
\text { grade professional, administrative and managerial } \\
\text { occupations and higher grade technician and supervisory } \\
\text { occupations. (3) Intermediate occupations. (4) Small } \\
\text { employer and self employed occupations (exc agriculture } \\
\text { etc). }\end{array}$ & 0 & 1 & $45.97 \%$ \\
\hline No reported class & Unknown occupation, but included in the analysis & 0 & 1 & $7.23 \%$ \\
\hline Income_q1 & 1. income quartile & 0 & 1 & $17.93 \%$ \\
\hline Income_q2 & 2. income quartile & 0 & 1 & $19.83 \%$ \\
\hline Income_q3 & 3. income quartile & 0 & 1 & $17.69 \%$ \\
\hline Income_q4 & 4. income quartile (reference category) & 0 & 1 & $19.89 \%$ \\
\hline No reported income & Unknown income, but included in the analysis & 0 & 1 & $24.66 \%$ \\
\hline No social support & No one to discuss personal matters with & 0 & 1 & $10.62 \%$ \\
\hline Limited social network & $\begin{array}{l}\text { Meet with friends, relatives, colleagues less than once a } \\
\text { week }\end{array}$ & 0 & 1 & $40.54 \%$ \\
\hline \multicolumn{5}{|c|}{ Country level variables $(n=21)$} \\
\hline Welfare regime & Country classification & & & \\
\hline 1 & Scandinavian (DK, FI, NO, SE) (reference category) & 0 & 1 & $19.43 \%$ \\
\hline 2 & Bismarckian (AT, BE, CH, DE, FR, LU, NL) & 0 & 1 & $34.73 \%$ \\
\hline 3 & Anglo-Saxon (GB, IE) & 0 & 1 & $8.39 \%$ \\
\hline 4 & South-European (ES, GR, IT, PT) & 0 & 1 & $19.39 \%$ \\
\hline 5 & East European (CZ, HU, PL, SI) & 0 & 1 & $18.06 \%$ \\
\hline
\end{tabular}

${ }^{a}$ Min.: minimum value, Max.; maximum value. $\mathrm{N}=65065$ for all cases. ${ }^{b}$ Mean for age. 
Table 2

Proportional variation of ill-health between individuals, regions and countries ${ }^{a}$

\begin{tabular}{|c|c|c|c|c|c|c|c|}
\hline Estimation & Statistics & & oor general hea & & Lin & ting longstandin & illness \\
\hline $2^{\text {nd }}$ order PQL & $\begin{array}{l}\text { Level } \\
\text { Variance } \\
\% \text { of total variance }\end{array}$ & $\begin{array}{c}\text { Individual } \\
3.290 \\
89.85 \%\end{array}$ & $\begin{array}{c}\text { regional } \\
0.054(0.008) \\
1.47 \%\end{array}$ & $\begin{array}{c}\text { national } \\
0.318(0.071) \\
8.68 \%\end{array}$ & $\begin{array}{c}\text { Individual } \\
3.290 \\
95.19 \%\end{array}$ & $\begin{array}{c}\text { regional } \\
0.049(0.008) \\
1.41 \%\end{array}$ & $\begin{array}{c}\text { national } \\
0.126(0.029) \\
3.64 \%\end{array}$ \\
\hline $\begin{array}{l}\text { MCMC (priors from } \\
2^{\text {nd }} \text { order PQL) }\end{array}$ & $\begin{array}{l}\text { Level } \\
\text { Variance } \\
\% \text { of total variance }\end{array}$ & $\begin{array}{c}\text { Individual } \\
3.290 \\
89.48 \% \\
\end{array}$ & $\begin{array}{c}\text { regional } \\
0.032(0.012) \\
0.87 \% \\
\end{array}$ & $\begin{array}{c}\text { national } \\
0.355(0.086) \\
9.65 \% \\
\end{array}$ & $\begin{array}{c}\text { Individual } \\
3.290 \\
95.59 \% \\
\end{array}$ & $\begin{array}{c}\text { regional } \\
0.017(0.008) \\
0.49 \% \\
\end{array}$ & $\begin{array}{c}\text { national } \\
0.135(0.032) \\
3.92 \% \\
\end{array}$ \\
\hline $1^{\text {st }}$ order MQL & $\begin{array}{l}\text { Level } \\
\text { Variance } \\
\% \text { of total variance }\end{array}$ & $\begin{array}{c}\text { Individual } \\
3.290 \\
91.19 \%\end{array}$ & $\begin{array}{c}\text { regional } \\
0.035(0.006) \\
0.97 \%\end{array}$ & $\begin{array}{c}\text { national } \\
0.283(0.063) \\
7.84 \%\end{array}$ & $\begin{array}{c}\text { Individual } \\
3.290 \\
95.28 \%\end{array}$ & $\begin{array}{c}\text { regional } \\
0.047(0.008) \\
1.36 \%\end{array}$ & $\begin{array}{c}\text { national } \\
0.116(0.027) \\
3.36 \%\end{array}$ \\
\hline $\begin{array}{l}\text { MCMC (priors from } \\
1^{\text {st }} \text { order MQL) }\end{array}$ & $\begin{array}{l}\text { Level } \\
\text { Variance } \\
\% \text { of total variance }\end{array}$ & $\begin{array}{c}\text { Individual } \\
3.290 \\
90.29 \%\end{array}$ & $\begin{array}{c}\text { regional } \\
0.000(0.000) \\
0.00 \% \\
\end{array}$ & $\begin{array}{c}\text { national } \\
0.354(0.083) \\
9.71 \% \\
\end{array}$ & $\begin{array}{c}\text { Individual } \\
3.290 \\
95.22 \% \\
\end{array}$ & $\begin{array}{c}\text { regional } \\
0.003(0.001) \\
0.87 \% \\
\end{array}$ & $\begin{array}{c}\text { national } \\
0.134(0.033) \\
3.91 \% \\
\end{array}$ \\
\hline
\end{tabular}

a 3 -level variance component models of poor general health and limiting longstanding illness using both IGLS and MCMC estimation based on $2^{\text {nd }}$ order PQL and $1^{\text {st }}$ order MQL estimation. 
Table 3

A multilevel analysis of poor general health on individual-level variables (model 1) and welfare regime types (model 2$)^{a}$

\begin{tabular}{|c|c|c|c|}
\hline \multirow[t]{2}{*}{ Categories } & Variables & $\begin{array}{c}\text { Model } 1 \\
\text { OR }(95 \% \mathrm{Cl})\end{array}$ & $\begin{array}{c}\text { Model } 2 \\
\text { OR }(95 \% \mathrm{Cl}) \\
\end{array}$ \\
\hline & Intercept & $0.02(0.02-0.02)$ & $0.01(0.01-0.02)$ \\
\hline \multirow{2}{*}{ Sex } & Men & 0 & 0 \\
\hline & Women & $1.36(1.06-1.76)$ & $1.37(1.19-1.59)$ \\
\hline Age & Age & $1.04(1.04-1.05)$ & $1.05(1.04-1.05)$ \\
\hline \multirow{3}{*}{$\begin{array}{l}\text { Level of } \\
\text { education }\end{array}$} & Primary education & $1.66(1.57-1.75)$ & $1.65(1.56-1.75)$ \\
\hline & Upper secondary & $1.24(1.17-1.30)$ & $1.23(1.17-1.30)$ \\
\hline & Post secondary / tertiary & 1 & 1 \\
\hline \multirow{3}{*}{$\begin{array}{l}\text { Occupational } \\
\text { class }\end{array}$} & Lower classes & $1.29(1.23-1.35)$ & $1.29(1.23-1.36)$ \\
\hline & Higher classes & 1 & 1 \\
\hline & No reported class & $1.24(1.15-1.35)$ & $1.25(1.15-1.35)$ \\
\hline \multirow{5}{*}{ Income } & 1.quartile & $1.75(1.64-1.87)$ & $1.75(1.63-1.87)$ \\
\hline & 2.quartile & $1.38(1.29-1.47)$ & $1.38(1.29-1.47)$ \\
\hline & 3.quartile & $1.13(1.06-1.21)$ & $1.13(1.06-1.21)$ \\
\hline & 4.quartile & 1 & 1 \\
\hline & No reported income & $1.27(1.19-1.35)$ & $1.27(1.19-1.35)$ \\
\hline \multirow{2}{*}{ Social network } & No social network & $1.22(1.17-1.26)$ & $1.21(1.16-1.26)$ \\
\hline & Has a social network & 1 & 1 \\
\hline \multirow{2}{*}{ Social support } & No discussion partner & $1.56(1.48-1.65)$ & $1.56(1.48-1.65)$ \\
\hline & Discussion partner & 1 & 1 \\
\hline \multirow{5}{*}{$\begin{array}{l}\text { Welfare } \\
\text { regime }\end{array}$} & Scandinavian & & 1 \\
\hline & Anglo-Saxon & & $0.76(0.47-1.24)$ \\
\hline & South European & & $1.90(1.56-2.31)$ \\
\hline & Bismarckian & & $1.19(0.98-1.46)$ \\
\hline & East European & & $3.27(2.47-4.33)$ \\
\hline \multirow[t]{4}{*}{ Statistics } & Between country variation $\left(\mathrm{u}_{0 \mathrm{i}}\right)$ & $0.355(p<0.01)$ & $0.189(p<0.01)$ \\
\hline & Proportion of level-2 variation & $0.87 \%$ & $0.00 \%$ \\
\hline & Proportion of level-3 variation & $9.65 \%$ & $5.43 \%$ \\
\hline & $\mathrm{N}$ & 65065 & 65065 \\
\hline
\end{tabular}


a 2 three-level random intercept models of poor general health using MCMC estimation based on $2^{\text {nd }} \mathrm{PQL}$ estimation. Model 1 has individual-level variables only, while model 2 includes welfare regime typologies + model 1 . 